\title{
Future yields assessment of bioenergy crops in relation to climate change and technological development in Europe
}

\author{
Salvatore L. Cosentino, ${ }^{1}$ Giorgio Testa, ${ }^{1}$ Danilo Scordia, ${ }^{1}$ Efthimia Alexopoulou ${ }^{2}$ \\ ${ }^{1}$ Department of Agricultural and Food Science - DISPA, University of Catania, Italy; ${ }^{2}$ Center for \\ Renewable Energy Sources and Saving - CRES, Pikermi - Attiki, Greece
}

\begin{abstract}
Bioenergy crops are expected to play an important role in reducing $\mathrm{CO}_{2}$ emission, in energy supply and in European energy policy. However, a sustainable bioenergy supply must be resilient to climate change and the impacts on agriculture at both global and regional scale. The purpose of this study was to forecast the potential distribution of several bioenergy crops based on agronomic and environmental constrains under current conditions and future scenarios (2020 and 2030) in European Union. Potential biomass yield, according to the category end use product achievable in each environmental zone of Europe at present and in the future available land have been also studied. Future yields were assessed according to two factors: technological development and climate change: the former was based on prospect of DG-Agriculture for conventional crops and expert judgments for bioenergy crops, while the latter based on relevant research papers and literature reviews which used site-specific crop growth models. Yields are expected to increase in northern Europe due to climate change and technological development, while in southerneastern Europe the negative effect of climate change will be mitigated by the technological development. The estimated total biomass production in Europe, on the basis of future yields and surplus land made available for energy crops, may not be sufficient to meet the needs of bioenergy supply as claimed in the European directive 2009/28/EC.
\end{abstract}

Correspondence: Salvatore L. Cosentino, Department of Agricultural and Food Science - DISPA, University of Catania, via Valdisavoia 5, 95123 Catania, Italy. Tel. +39.095.234411 - Fax: +39.095.234449.

E-mail: cosentin@unict.it

Key words: climate change, technological development, bioenergy crops, future yields.

Acknowledgements: the results presented in this work were produced under the project Future Crops for Food, Feed, Fiber and Fuel - 4F CROPS funded by the Seventh Framework Programme of the European Commission under Grant Agreement nr. 212811 (www.4fcrops.eu).

Received for publication: 25 October 2011.

Accepted for publication: 27 February 2012.

CCopyright S.L. Cosentino et al., 2012

Licensee PAGEPress, Italy

Italian Journal of Agronomy 2012; 7:e22

doi:10.4081/ija.2012.e22

This article is distributed under the terms of the Creative Commons Attribution Noncommercial License (by-nc 3.0) which permits any noncommercial use, distribution, and reproduction in any medium, provided the original author(s) and source are credited.

\section{Introduction}

In the last 50 years, the European agricultural land has decreased by about 15\% in front of an increase of 14\% in European population and food demand (FAOSTAT, http://faostat.fao.org/site/291/default.aspx). This was possible thanks to the advances in agricultural technologies and breeding programs that allowed a huge increase in crop productivity. The reduction of agricultural land associated with the reduction of conventional crop land due to the effect of crop yield increase, may provide new challenges for the introduction of non conventional crops, such as bioenergy crops.

In this regard, it should be reminded that between 17.5 and 21.1 million hectares of arable land need to be cultivated with dedicated energy crops in order to achieve the European renewable energy targets, which imposes an obligation to increase the amount of the renewable energy in the EU to $20 \%$ of the total energy consumption by 2020 , with $10 \%$ biofuels in the transport sector in order to reduce the $\mathrm{CO}_{2}$ emissions by $20 \%$ compared to 2005 (European Commission, 2009). Accordingly, bioenergy crops are expected to play an important role in achieving long-term goals for energy policy in cutting $\mathrm{CO}_{2}$ emissions and contribute to the maintenance of energy supplies. However, great concerns have been expressed over the competition for land use between food and non-food cropping systems. It was considered that only if biomass is produced without encroaching on productive agricultural lands or displacing natural forests, it has the potential to reduce greenhouse gas (GHG) emissions while providing an alternative to fossil fuels (Tilman et al., 2009). In the frame of $4 \mathrm{~F}$ CROPS project (Alexopoulou, 2010), which was funded by the EU in order to survey and analyse all the parameters for a successful introduction of nonfood cropping systems along with food and fiber ones in EU-27, the total area potentially available for non-food crops in the EU-27 (excluding Cyprus and Malta) was estimated to be 13.2 million ha in the current situation (2003-2007), 20.5 million in 2020 and 26.2 million ha in 2030 (Krasuska et al., 2010). However, a sustainable energy supply must be resilient to climate change in which bioenergy crops are likely to play an important role.

Uncertainties in regional precipitation patterns, agricultural sensitivity to climate and crop response to rising atmospheric $\mathrm{CO}_{2}$ concentration and temperature affects our ability to project climate impacts on agriculture at both global and regional scale. Most of global climatic models (GCMs) are able to provide information on main climatic variables (e.g. air temperature, precipitation, humidity, radiation and wind speed), however, much effort has been paid in downscaling the horizontal spatial scale to $50 \mathrm{~km}$ or less using regional climatic models (RCMs) to better predict those variables (Olesen et al., 2007). Several studies on future crop yield and distribution indicate that different climatic models produce different regional patterns (Audsley et al., 2006; Tuck et al., 2006; Olesen et al., 2007; Rötter et al., 2011). One common approach is making projections on future yields using past trends in 
Table 1. Climatic characteristics of the European environmental zones.

\begin{tabular}{|c|c|c|c|c|c|c|c|}
\hline \multirow[t]{2}{*}{ Environmental zone } & \multicolumn{2}{|c|}{ Temperature } & \multicolumn{2}{|c|}{ Rainfall } & \multirow{2}{*}{$\begin{array}{c}\text { Months } \\
<0^{\circ} \mathrm{C}\end{array}$} & \multirow{2}{*}{$\begin{array}{l}\text { Active temperature } \\
\qquad>10^{\circ} \mathrm{C}\end{array}$} & \multirow{2}{*}{$\begin{array}{c}\text { Growth season } \\
\text { days }\end{array}$} \\
\hline & Min & Max & Oct-Apr & May-Sept & & & \\
\hline NEM & 2.4 & 9.3 & 309.8 & 310.8 & 4.6 & 2717 & 196 \\
\hline $\mathrm{CON}$ & 4.2 & 13.1 & 380.9 & 393.4 & 4.1 & 3294 & 227 \\
\hline ATN & 4.5 & 11.2 & 760.7 & 437.9 & 1.9 & 3198 & 255 \\
\hline ATC & 6.2 & 13.6 & 563.5 & 349.4 & 0.2 & 3849 & 296 \\
\hline LUS & 8.4 & 17.4 & 851.5 & 321.7 & 0.0 & 4749 & 353 \\
\hline PAN & 6.1 & 15.6 & 277.7 & 291.9 & 2.6 & 4099 & 250 \\
\hline MDN & 8.2 & 18.1 & 477.8 & 218.1 & 0.4 & 5104 & 335 \\
\hline MDS & 11.2 & 21.1 & 470.1 & 114.4 & 0.0 & 6021 & 363 \\
\hline
\end{tabular}

NEM, Nemoral; CON, Continental; ATN, Atlantic north; ATC, Atlantic central; LUS, Lusitanian; PAN, Pannonia; MDN, Mediterranean north; MDS, Mediterranean south.

yield development. It was used in REFUEL project (Fischer et al., 2007) and the European Environmental Agency study on bioenergy potentials (EEA, 2007). In other studies, future yields growth rates are based on expert judgments (Ericsson and Nilsson, 2006; Kunikowski et al., 2006).

The purpose of this study was to forecast the potential distribution of several bioenergy crops based on agronomic and environmental constrains under current conditions and future scenarios (2020 and 2030) in European Union. Potential biomass yield, according to the category end use product achievable in each environmental zone of Europe at present and in the future available land have been also studied.

\section{Materials and methods}

\section{Analyzed area}

As climatic conditions do not follow national boundaries and the choice of a dedicated crop depends, primarily, upon its suitability to the climatic conditions of a specific country or region, it was decided to use the climatic stratification proposed by Metzger et al. (2005) and Jongman et al. (2006). In their work, Europe was divided into 13 environmental zones of homogenous bioclimatic conditions as a consequence of main meteorological parameters (e.g. maximum and minimum temperature, rainfalls, months of temperature below $0^{\circ} \mathrm{C}$ ), as shown in Table 1. From an agronomic point of view, we focus on eight environmental zones to indicate possible energy cropping choices: Nemoral, Continental, Pannonian, Atlantic north, Atlantic central, Lusitanian, Mediterranean north and Mediterranean south. Alpine north, Alpine south, Mediterranean Mountain and Boreal were not included because of severe climatic and landscape constrains, while Anatolian because out of European boundaries.

Nemoral (NEM) covers the lowlands and undulating plains of South Scandinavia and the North-West of the Russian Plain including the Baltic countries. Continental (CON) is mostly on the plains and lowlands of central and eastern Europe, uplands and low mountains of the Balkan peninsula; it is situated from the Ardennes in the west to the Ukraine in the east. Pannonian (PAN) lies on lowlands valleys and mountain peripheries on the middle-lower Danube and on plainsand of Black-Sea. Atlantic north (ATN) covers uplands and low mountains in central and northern Britain, northern Ireland and western coast of Scandinavia, lowlands and plains of Jutland and north Germany. Atlantic central (ATC) is situated in Ireland, south Britain, north and central France, Belgium, The Netherlands and west Germany. Lusitanian (LUS) lies from west Atlantic coast of France to north Atlantic cost of Spain and north-central Atlantic cost of Portugal. Mediterranean north (MDN) occupies lowlands in northern Italy, Spain,
Table 2. Surplus land from the land allocation model.

\begin{tabular}{lccc}
\hline Environmental zone & \multicolumn{3}{c}{ Area (ha) } \\
NEM & Base case & 2020 & 2030 \\
ATN & 470,200 & $1,006,530$ & $1,328,800$ \\
\hline ATC & 867,000 & $1,298,520$ & $1,610,400$ \\
CON-W & $1,444,300$ & $2,106,850$ & $2,549,000$ \\
\hline CON-E & $1,586,100$ & $2,204,800$ & $2,651,700$ \\
\hline LUS & $1,656,700$ & $4,181,300$ & $5,926,800$ \\
PAN & 562,400 & 718,770 & 838,100 \\
MDN & $1,255,200$ & $3,340,400$ & $5,205,600$ \\
MDS & $2,063,300$ & $2,164,420$ & $2,306,400$ \\
TOT & $2,454,900$ & $2,476,580$ & $2,512,800$ \\
\hline
\end{tabular}

NEM, Nemoral; ATN, Atlantic north; ATC, Atlantic central; CON-W, Continental west; CON-E, Continental east; LUS, Lusitanian; PAN, Pannonian; MDN, Mediterranean north; MDS, Mediterranean south. Processing of data from Krasuska et al., 2010.

Greece, southern France and Portugal, uplands and low mountains in southern Mediterranean. Mediterranean south (MDS) occupies plains and uplands in southern Mediterranean (Italy, Spain, Portugal and Greece) and some lowlands in the northern (EBONE, 2010).

\section{Available land in the environmental zones}

In this study, surplus land was defined as the potential available land for non-food crops after the allocation of available land resources for the production of different food and feed crops. Values of surplus land were those reported by Krasuska et al. (2010), in which the major drivers in the scenarios established were the expected growth in crop production intensity and change in food demand. The work was based on the Nomenclature of Territorial Units for Statistics (NUTS). The estimations were performed for NUTS-2 regions for all countries, except for Germany and the UK, for which NUTS-1 level was considered. For Denmark, Estonia, Lithuania and Luxemburg NUTS-2 regions are equal to national NUTS-0 levels. In order to cope with the aim of this work, countries belonging to a specific environmental zone were summed up in order to estimate the available land in the analysed environmental zone. Available land (ha) in the current situation (2003-2007), and future scenario (2020 and 2030) is reported in Table 2. CON environmental zone covers a high number of countries with different socio-economic and technological level. In order to analyse the environmental zones as homogeneous as possible, CON was split into CON-West and CON-East; in the former belongs the countries of the western part, while in the latter the eastern countries of CON environmental zone, respectively. 
Table 3. Constrains of the selected bioenergy crops.

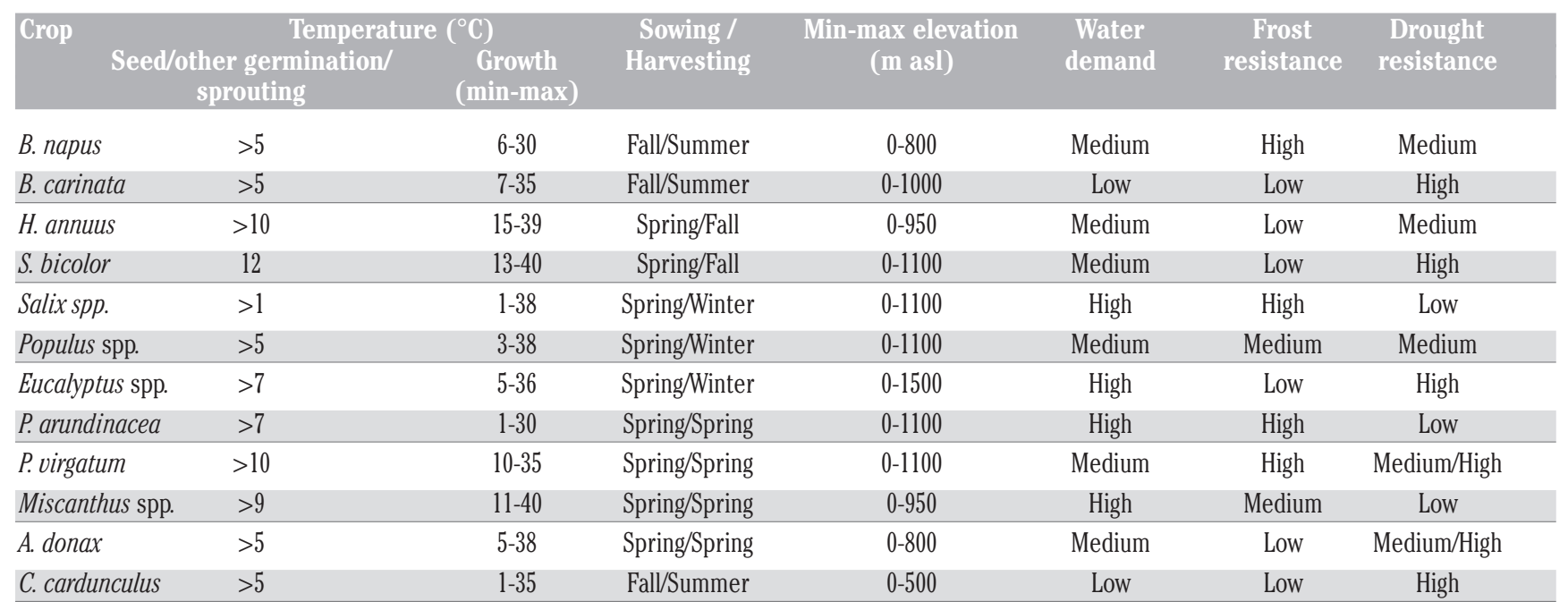

\section{Choice of the bioenergy crop}

The traditional food or feed crops and the so-called dedicated bioenergy crops (never or rarely cultivated) under study were categorized according to their end use product: oil, sugar/starch, short rotation coppice (SRC) and herbaceous lignocellulosic crops. The length of growing season, temperature, water requirement, drought and frost resistance are the main factors imposing the use of different energy crops for the selected environmental zones (Table 3). No accounts were taken of photoperiodic response, nutrients requirements, soil type, slope or other potential limitations.

\section{Assessment of future crop yield}

A methodological issue has regarded the choice of the crop and the prevision on future crop yields. In the frame of $4 \mathrm{~F}$ CROPS project, the work on future crop yields was approached using existing models. At the beginning of the project, experts belonging to the 4FCROPS consortium used WOFOST crop growth model to forecast crop yields and crops development in Europe.

Long-term series of simulated water limited yields (1993-2007) for the main arable crops derived from Crop Growth Monitoring System (CGMS) database were used in the 4F CROPS project and were compared to statistical yields from EUROSTAT (http://epp.eurostat.ec. europa.eu/portal/page/portal/statistics/themes). In some cases the crop growth model strongly overestimates the simulated water-limited yields in years with serious drought stress and in countries where water is considered a limiting factor (e.g. countries belonging to Mediterranean environments), as well as in countries with elevated rainfall or lower technological development (e.g. countries belonging to central-north or north-east Europe). Underestimations, on the other hand, were observed with spring-summer crops, such as sunflower and maize in countries belonging to Mediterranean environments. Crop simulation studies are often limited with respect to the number and kind of crops, spatial coverage and daily meteorological dataset recovery. Moreover, phenological, biological and physiological processes linked to dedicated bioenergy crops are poorly understood to date.

In the present study, in order to assess future crop yields two different factors were taken into account: technological developments (crop management, breeding, etc.) and climate change $\left(\mathrm{CO}_{2}\right.$, temperature, precipitation, etc.). Future yields were assumed without taking into account the irrigation practice, with the exception of sorghum in South Mediterranean environment. Technological developments are based on
Table 4. Annual growth rate based on technological developments.

\begin{tabular}{lccl} 
Crops & EU-15 & EU-12\# & Comments \\
Traditional (e.g. Maize) & +0.25 & +0.55 & DG Agriculture \\
Crops of new introduction & +1.1 & +0.8 & Expert judgement \\
\hline
\end{tabular}

${ }^{\circ}$ EU-15, central-west European countries; ${ }^{\# E U-12, ~ n e w ~ m e m b e r ~ S t a t e s ~(e a s t ~ E u r o p e) ; ~}{ }^{\circledR}$ Brassica napus, Beta vulgaris, Zea mais, Helianthus annuus; ${ }^{\wedge}$ Phalaris arundinacea, Panicum virgatum, Miscanthus spp., Arundo donax, Cynara cardunculus, Brassica carinata, Sorghum bicolor, SRC (Populus spp., Salix spp., Eucalyptus spp.).

prospects for agriculture, agricultural markets and income in the EU elaborated by the European Commission's Directorate-General for Agriculture and Rural Development (2007). It was estimated that within a 10-year period starting from 2007 maize yields in the EU-27 (old and new member States) will grow at an average rate of $0.4 \%$ per annum, which would stand at $0.55 \%$ in the EU-12 (new member States) and $0.25 \%$ in the EU-15 (old member States) (Table 4) (Krasuska et al., 2010). However, the yield increase rates have slowed down considerably over the last decade, which could suggest that the production is close to the technological frontier, especially in the EU-15 countries, as have been also reported by Olesen et al. (2011). The DG Agriculture (European Commission Directorate-General for Agriculture and Rural Development, 2007) assumes higher yield increase for the EU-12 compared to the EU-15, since significant gains in yields can still be achieved there by the introduction of more productive varieties and higher production standards. Therefore, taking into account the time horizon investigated in this study (2020 and 2030), we made an expert assumption that the technological annual growth rate of the conventional or much studied crops would show 0.25 and $0.55 \%$ of technological development in EU-15 and EU-12, respectively. On the other hand, dedicated bioenergy crops are rarely or never cultivated, with high possibility of improvements; in this case experts assumption stated that technological annual growth rate for those crops would show 0.8 and $1.1 \%$ of annual growth rate in EU-12 and EU15 , respectively, as was the case of cereal yields in the past decades (European Commission Directorate-General for Agriculture and Rural Development, 2007). Regarding climate change for each future crop scenario different coefficients were carried out, according to published studies and relevant research works which used crop models calibrated to the environment under study, literature reviews and expert judgments (Tables 5 and 6 ). In order to compare different future crop yields, 
की

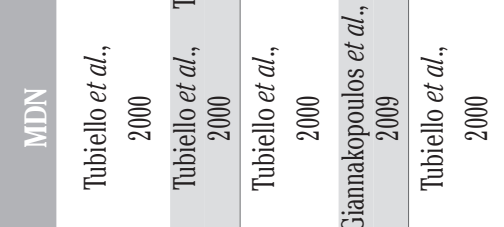

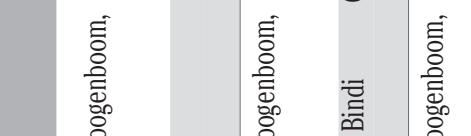

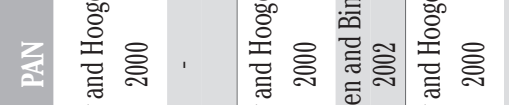

产

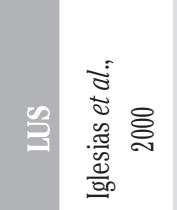

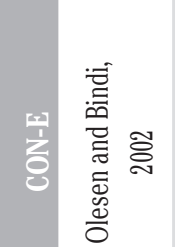

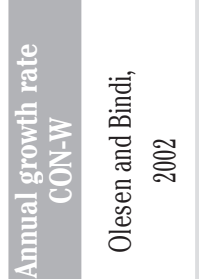

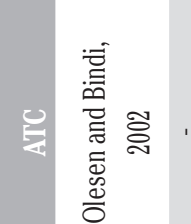

密

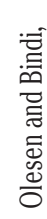

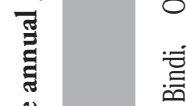

䒿 종

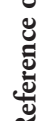

先

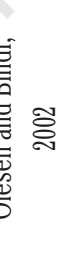

䒿 气ิ

峁

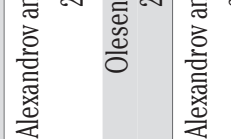

空

๘

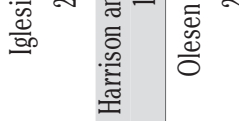

.ี

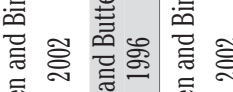

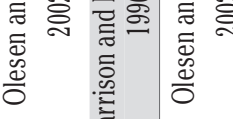

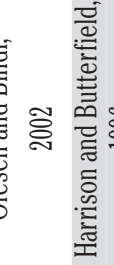

㺼

灾 灾

这
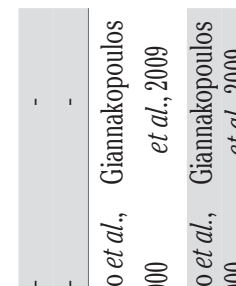

i

을 을 을 을

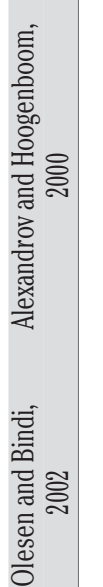

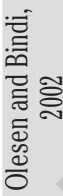

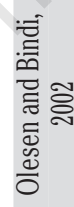

预

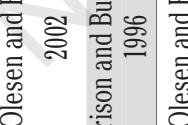
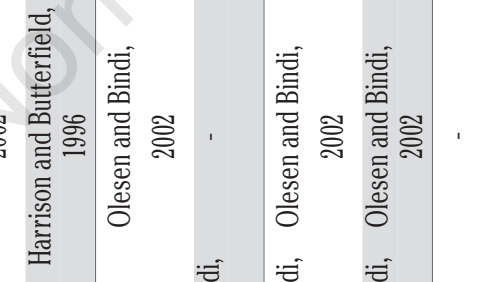

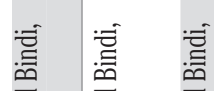

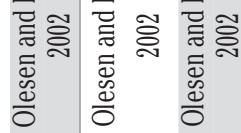

है 
A2 scenario (IPCC - Special Report on Emissions Scenarios, 2000) or double $\mathrm{CO}_{2}$ level was used from those studies and simulated in our analysis in a time horizon starting from base case (average value 20032007) to 2020 and 2030. However, technological and climatic variations have been usually reported at national or macroarea level (e.g. north, south, west or east Europe). In these cases, for the need to match literature data with our analysis, the coefficients, both technological and climatic, have been adapted from the nation or macroarea to the studied environmental area that fell in the surplus land, and subsequently summed up to obtain a single factor to be used as annual growth rate to assess 2020 and 2030 crop yields.

The results of future crop yield under each environmental zone have been multiplied by the potential available land to assess the total biomass achievable in EU-27 (less Cyprus and Malta), under current situation, in 2020 and in 2030 .

\section{Yields}

In the present study, current yields for the conventional crops were assessed according to statistical data derived from EUROSTAT and FAOSTAT database (average value 2003-2007), while the yields of dedicated bioenergy crops from research papers, literature reviews and expert judgments (Table 7). Yields have been reported as minimum, average and maximum achievable, hypothesizing two types of soils (agricultural and marginal) and two types of energy level (optimal and low input).

Agricultural land refers to a flat soil, characterized by physical and chemical composition at optimal ranges (e.g. absence of rocks and stones, good mineral ratio, $\mathrm{pH}$, organic matter, depth, salinity, cation exchange capacity, exchangeable sodium percentage, rich in micro, meso and macro soil biota, etc.). Marginal land is a very wide concept that could include several types and categories of soil and the marginality of soil could be ascribed when one or some of the aforementioned parameters are out of the optimal range, like for example soil with mechanical limitations because of stones, steep slopes, shallow or weathered, low organic matter content, high salinity, etc. Optimal input is based on the use of the present conventional resources (economic and energetic). Fertilizers, chemical weed and pest control are used to achieve maximal yields or economic returns, as well as modern mechanization methods with use of high yielding varieties and hybrids. Low input level refers to no significant or very low level of input, such as artificial pesticides, fertilizers and machinery used.

In our assumption, average yields correspond to marginal land with optimal input or agricultural land with low input supply. Maximum yield is referred to agricultural land with optimal input, while minimum yield is referred to marginal land with low input supply.

When possible, maximum and minimum yields were taken up by the literature, while when one or some values were not reported, an assumption, depending by the crop response to energetic input in similar environments, was made: minimum yield (from -10 to $-60 \%$ respect to the average yields); maximum yield (from +10 to $+50 \%$ respect to the average yields).

\section{Results}

\section{Annual growth rate of energy crops}

Annual growth rate caused by climate change shows a general increase for all bioenergy crops under study and for the northern and central environmental zones, while it generally decrease for MDN, MDS and PAN environmental zones (Table 6). However, the negative effect of the above mentioned environmental zones is mitigated by the technological development as shown in Table 6. Among oil crops, sun-
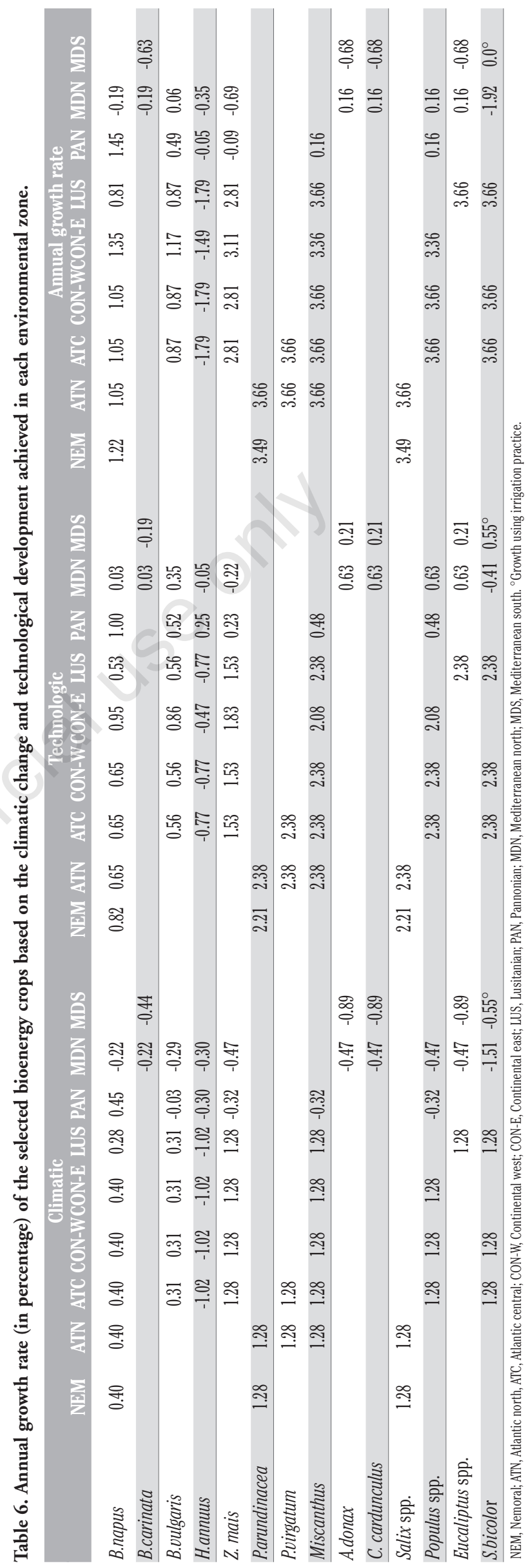

[page 158]

[Italian Journal of Agronomy 2012; 7:e22]

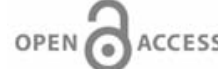




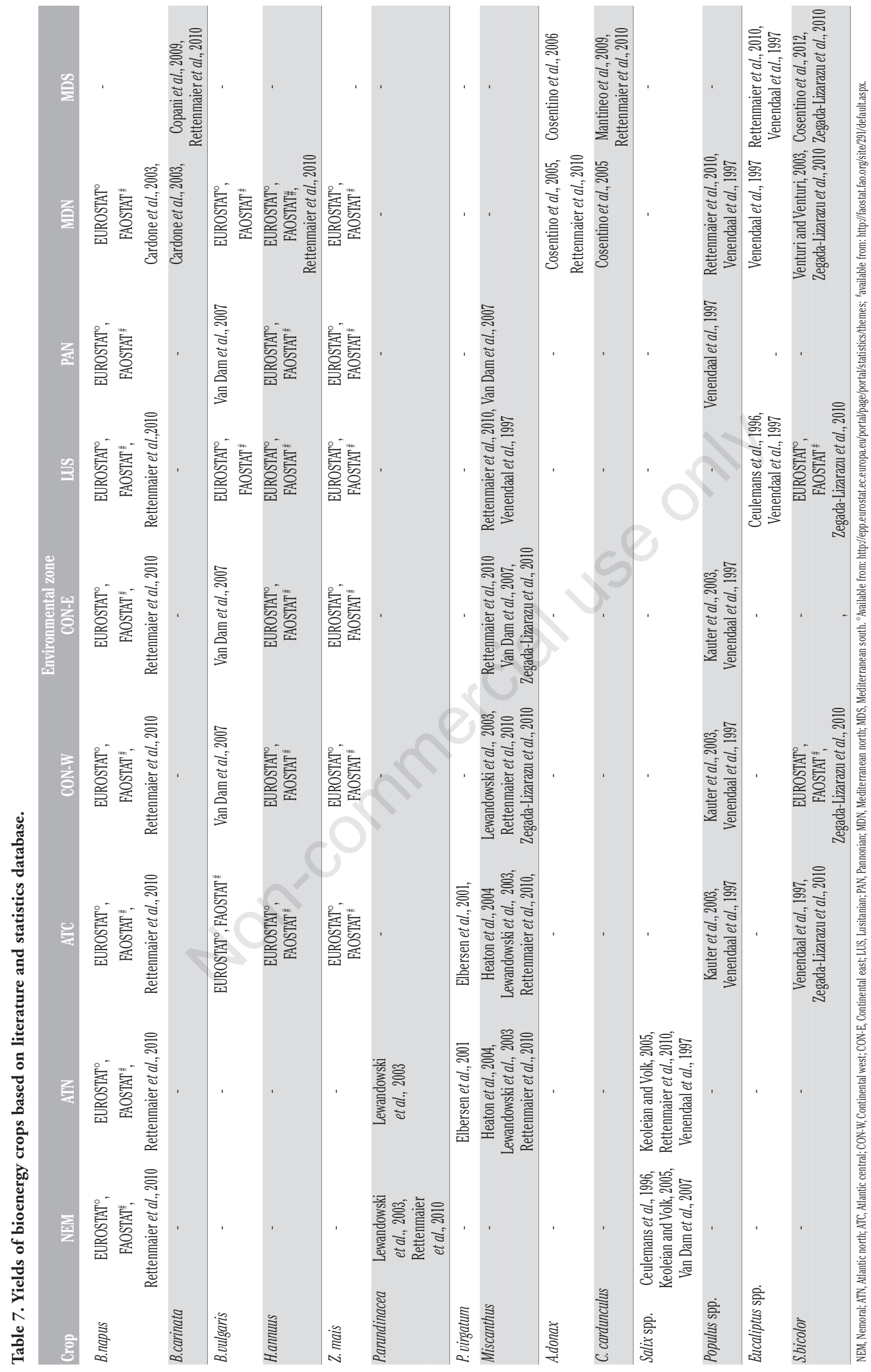


flower shows negative trends in almost all its environment of cultivation (from -0.05 to -0.77) except for PAN where it will grow at annual rate of $0.25 \%$. Rapeseed is present in all environmental zones except in MDS; in this last environment ethiopian mustard was chosen as crop for oil production due to its drought resistance compared to rapeseed. However, ethiopian mustard shows negative trend in MDS (-0.19\%) and almost stationary annual growth rate in MDN; vice versa, rapeseed shows annual growth rates ranging from $0.03 \%$ of MDN to $1.0 \%$ of PAN.

Among sugar/starch crops, highest annual growth rates were observed for sorghum (2.38\% in central and west Europe) because of the high possibility of improvements of this crop compared to sugarbeet and maize. However, an annual decrease $(-0.41 \%)$ is expected in MDN due to the possible reduction of spring-summer rainfall. In MDS its cultivation will be possible only using irrigation practice. Among the herbaceous, perennial, lignocellulosic energy crops, according to the temperature and water requirements, reed canary grass and switchgrass were found to be most suitable for environment of northern Europe, such as NEM, ATN and ATC, respectively, while miscanthus could be suitable for all environment except for the coldest (NEM) and lowest latitudes such as MDN and MDS due to its low drought resistance and high water demand. For those last environments giant reed and cardoon were considered as the best choose thanks to their medium/high drought resistance and medium to low water demand (Table 3). For short rotation woody crops (SRC) a north to south gradient, based on crop constrains offered by the environment, see willow more adapted to colder environments such as NEM and ATN since it has a relatively high resistance to frost, while poplar for a wide range of environment as ATC, CON-W, CON-E, PAN and MDN, however, often water availability is a limiting factor for its production. Eucalyptus finds its best allocation at lower latitude environments such as LUS, MDN, and MDS. The effects of technological development achievable will assure positive annual growth rates for those perennial bioenergy crops as shown in Table 6.

\section{Future crop yields}

Rapeseed is the most represented oil crop in the European environments. Yields, in the base case, are between $1.40 \mathrm{t} \mathrm{ha}^{-1}$ in PAN and CON-E to a maximum of $4.26 \mathrm{t} \mathrm{ha}^{-1}$ in ATC (Figure 1). The projections for 2020 and 2030 foreseen a minimum value of $1.48 \mathrm{tha}^{-1}$ in MDN in 2020 and 2030 and a maximum of 4.6 in the ATC, in the case of cultivation in soils with high optimal agronomic inputs. Considering the average output for climate zone, the minimum yields are expected in MDN for 2020 scenario $\left(2.25 \mathrm{t} \mathrm{ha}^{-1}\right)$ followed by NEM, CON-E and PAN (2.28, 2.31 and $2.38 \mathrm{tha}^{-1}$, respectively), while the highest are foreseen in ATC for 2020 to 2030 scenarios (4.08 and $4.36 \mathrm{t} \mathrm{ha}^{-1}$, respectively). By analyzing the yields recorded in CON-W and CON-E it is possible to point out that, in the average, yields are very different between the two areas (3.32 and $2.12 \mathrm{t} \mathrm{ha}^{-1}$ ) which are characterized by the same climate but composed of countries at different stages of technology development. The forecasts for 2020 and 2030 provide a gradual reduction of the gap between the two CON environmental zones mainly due to the possible technological transference to the east part.

Ethiopian mustard has been allocated to Mediterranean basin (MDN and MDS, respectively); medium productions detected in MDN and MDS are respectively equal to 3.15 and $2.22 \mathrm{tha}^{-1}$ in the base case; projection shows an almost constant trend in MDN $\left(3.17 \mathrm{t} \mathrm{ha}^{-1}\right.$ under 2030 scenario) and a slightly decrease in MDS 2030 scenario $\left(2.13 \mathrm{t} \mathrm{ha}^{-1}\right)$. In this case, the decrease of annual growth rate caused by climate change was mitigated by technological development.

Analyzing the average yields of sunflower in the different environments, minimum values are obtained in LUS $\left(1.47 \mathrm{t} \mathrm{ha}^{-1}\right)$ and maximum in CON-W (2.81 tha ${ }^{-1}$ ) (Figure 1). In the long term scenario it is expected a gap reduction between the yields of sunflower in EU-15 and
EU-12 countries, as evidenced by the reduction of the gap between CON-W and CON-E (from 0.96 in the base case to $0.70 \mathrm{t} \mathrm{ha}^{-1}$ in 2030 scenario). Sunflower generally shows a different response to increased temperature than winter crops and spring-summer C4 crops. Indeed, our estimation is in accordance to the findings of Harrison and Butterfield (1996), accounting for this to the fact that higher temperatures cause, in sunflower crop, increase in developmental rate, shorter growing season length, less time to accumulate biomass and, thus, lower yields. In winter crops, the raise of temperatures cause increase in developmental rate too, however, temperatures approach the optimum for physiological activities (i.e. photosynthesis and photosynthetate translocation) which counterweight the shorter biomass accumulation period due to shorter growing cycle. Moreover, C4 springsummer crops (e.g. sorghum and maize) are not affected by photorespiration as C3 spring-summer crops, and maintain high level of net photosynthesis at high temperatures. Even for sugar/starch crops, in the average yields, differences were observed between the yields in the different climatic zones. For sugarbeet lowest yields were observed in CON-E $8.45 \mathrm{t} \mathrm{ha}^{-1}$ while highest in LUS, with $16.06 \mathrm{t} \mathrm{ha}^{-1}$ (Figure 2). In maize both minimum and maximum yields have been observed in CON. The former in CON-E (3.65 tha-1) while the latter in CON-W $\left(7.44 \mathrm{t} \mathrm{ha}^{-1}\right.$ ) (Figure 2). Forecasts to 2030 include increases of more than $2 \mathrm{t} \mathrm{ha}^{-1}$ in both areas. Almost constant growth are expected in PAN (4.15 to 4.36 in 2030 scenario), while slight decreases in MDN (6.44 to $6.13 \mathrm{t} \mathrm{ha}^{-1}$, respectively).

On the other hand, substantial yield increases are expected for sorghum (Figure 2); LUS will see the highest growth ranging from, in the case of average yields, $17 \mathrm{tha}^{-1}$ of the current to $28.5 \mathrm{t} \mathrm{ha}^{-1}$ under 2030 scenario. This will be possible by using of early sowings and by the introduction of late maturity varieties. The lowest yields are observed in ATC $\left(8.5 \mathrm{t} \mathrm{ha}^{-1}\right)$ which will get similar production in 2030 as the one of the current case in MDN $\left(14.2 \mathrm{t} \mathrm{ha}^{-1}\right)$. In this last, due to the expected reduction in annual rainfall in the whole Mediterranean basin, yields are subjected to reduction. Therefore, in MDS sorghum cultivation will be possible only by using the irrigation practice for the whole crop cycle and, in this case, slight increase could happen.

Perennial, herbaceous, lignocellulosic crops, as well as short rotation coppicing are species which are under deep investigation worldwide as dedicated energy crops. As was for maize in the past decades, countries with higher technological background will put their effort to reduce the current bottlenecks of perennial, herbaceous, lignocellulosic crops and short rotation coppicing such as propagation, mechanization and other agronomic practices, in order to deliver genotypes, hybrids and high yielding varieties. For these reasons we believe that these two crop categories will grow at faster rates than the above mentioned crops for oil and sugar/starch. Reed canary grass is a species with high frost tolerance (Figure 3); in NEM its yield will grow, in the average, from 8.5 to $13.7 \mathrm{t} \mathrm{ha}^{-1}$, while in ATN from 8.7 to $14.7 \mathrm{t} \mathrm{ha}^{-1}$ in 2030 scenario. However, as for the following crops of new introduction, minimum and maximum values are reported since yields come mainly from experimental trials. In the minimum assumption $8 \mathrm{tha}^{-1}$ will be reached in 2030 in both environments, while 19 and $20 \mathrm{t} \mathrm{ha}^{-1}$ in NEM and ATN, respectively in the maximum one. Switchgrass is known as a temperate species with high tolerance to severe water stress conditions. In our choice it is allocated in ATN and ATC. Yields are 4.5 (minimum), 7.4 (average) and $10 \mathrm{tha}^{-1}$ (maximum) in the current case to 7.6, 12.4 and 16.8 (2030 scenario) in both environments and in the minimum, average and maximum assumption, respectively (Figure 3). Miscanthus has a broad range of genotypes able to grow in different environmental sites of Europe. Highest yield, in the average assumption and in the current case, were reported in LUS $\left(20 \mathrm{tha}^{-1}\right)$ followed by CON-W (17.7 t ha-1), while lowest in CON-E and PAN (10 t ha-1) (Figure 3). However, $4 \mathrm{t} \mathrm{ha}^{-1}$ are reported in ATN and ATC in the min- 


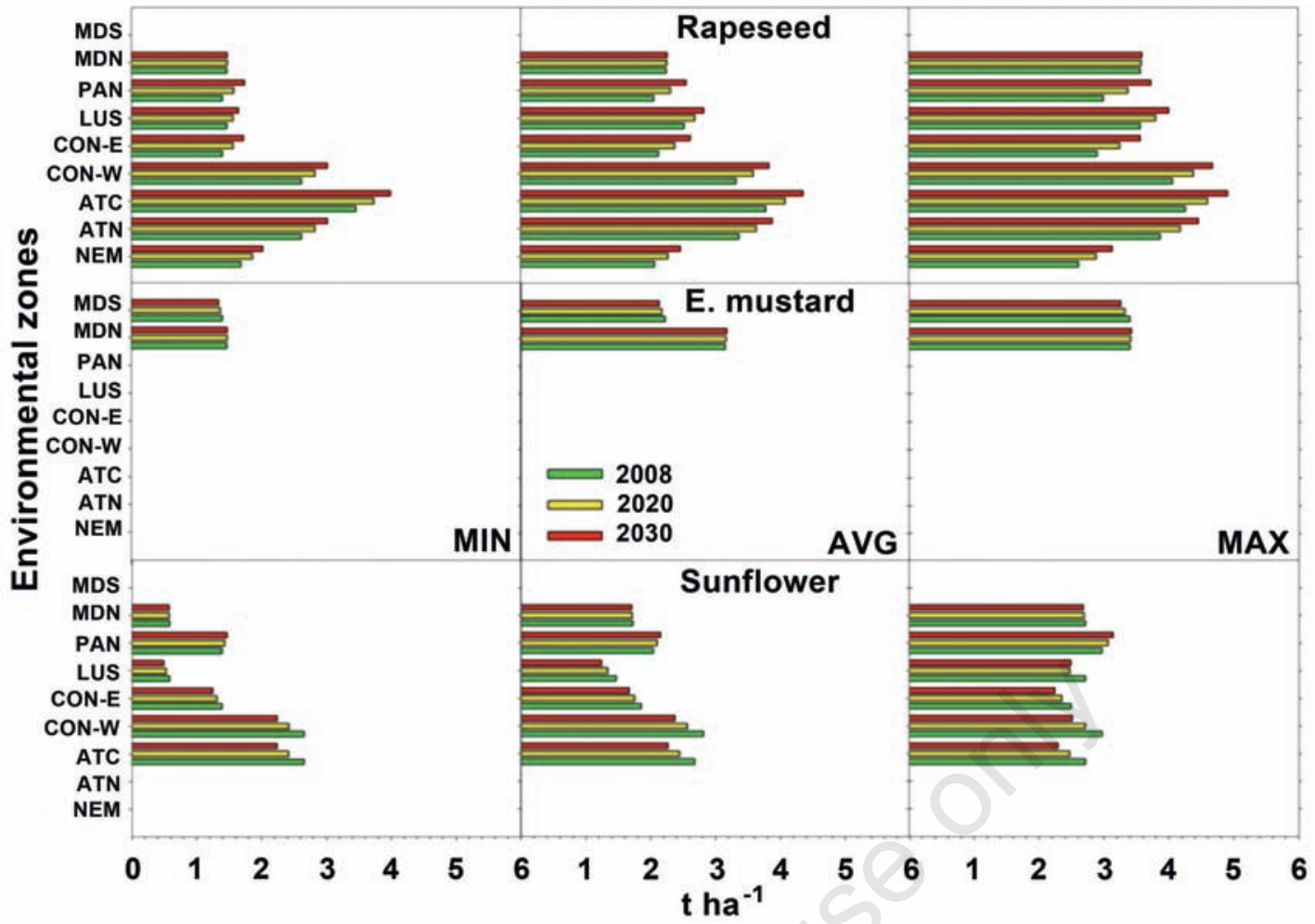

Figure 1. Base case and forecasts of minimum, average and maximum crop yields of oil crops at 2020 and 2030 scenarios (NEM, Nemoral; CON, Continental; ATN, Atlantic north; ATC, Atlantic central; LUS, Lusitanian; PAN, Pannonia; MDN, Mediterranean north; MDS, Mediterranean south).

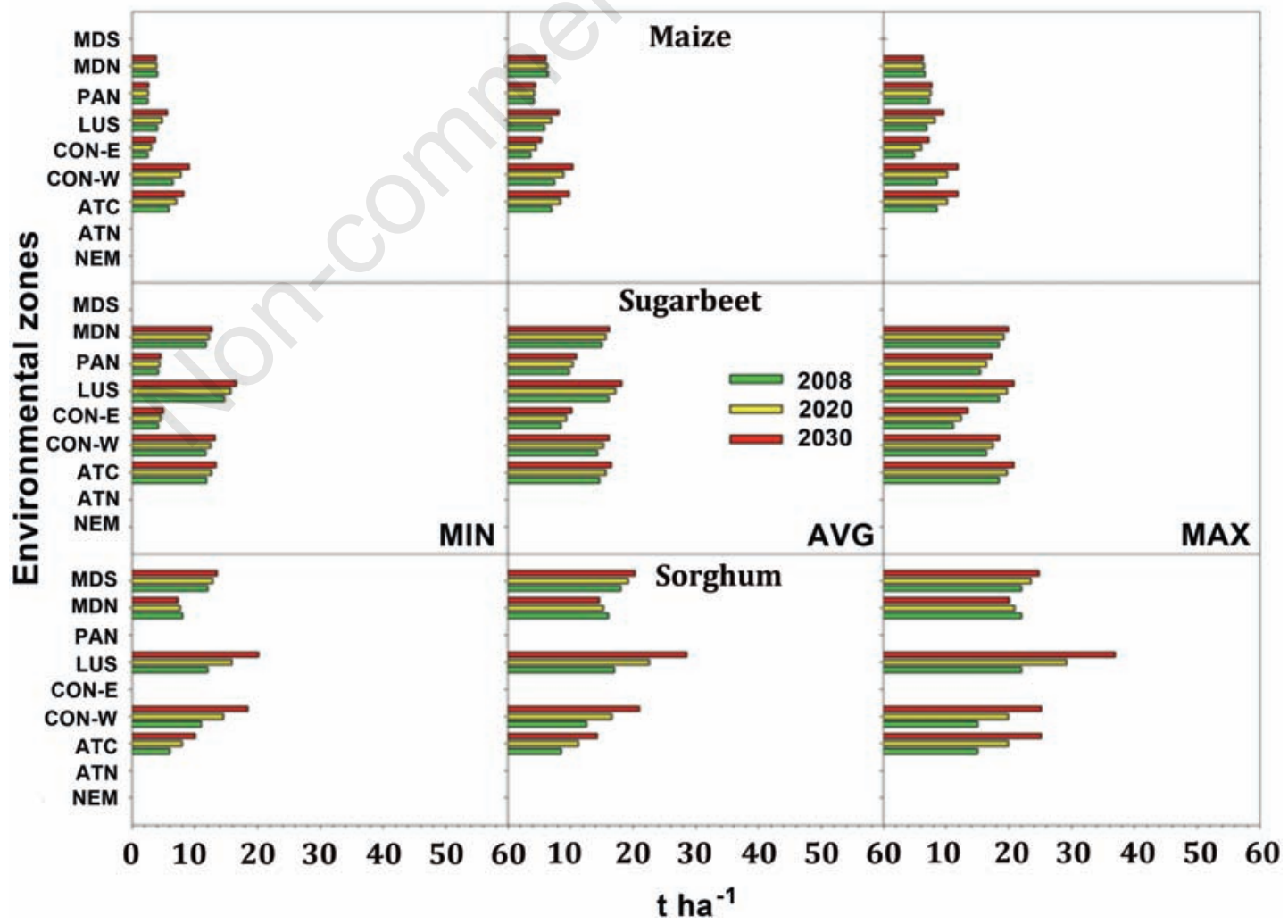

Figure 2. Base case and forecasts of minimum, average and maximum crop yields of sugar and starch crops at 2020 and 2030 scenarios (NEM, Nemoral; CON-W, Continental west; CON-E, Continental east; ATN, Atlantic north, ATC, Atlantic central; LUS, Lusitanian; PAN, Pannonia; MDN, Mediterranean north; MDS, Mediterranean south). 


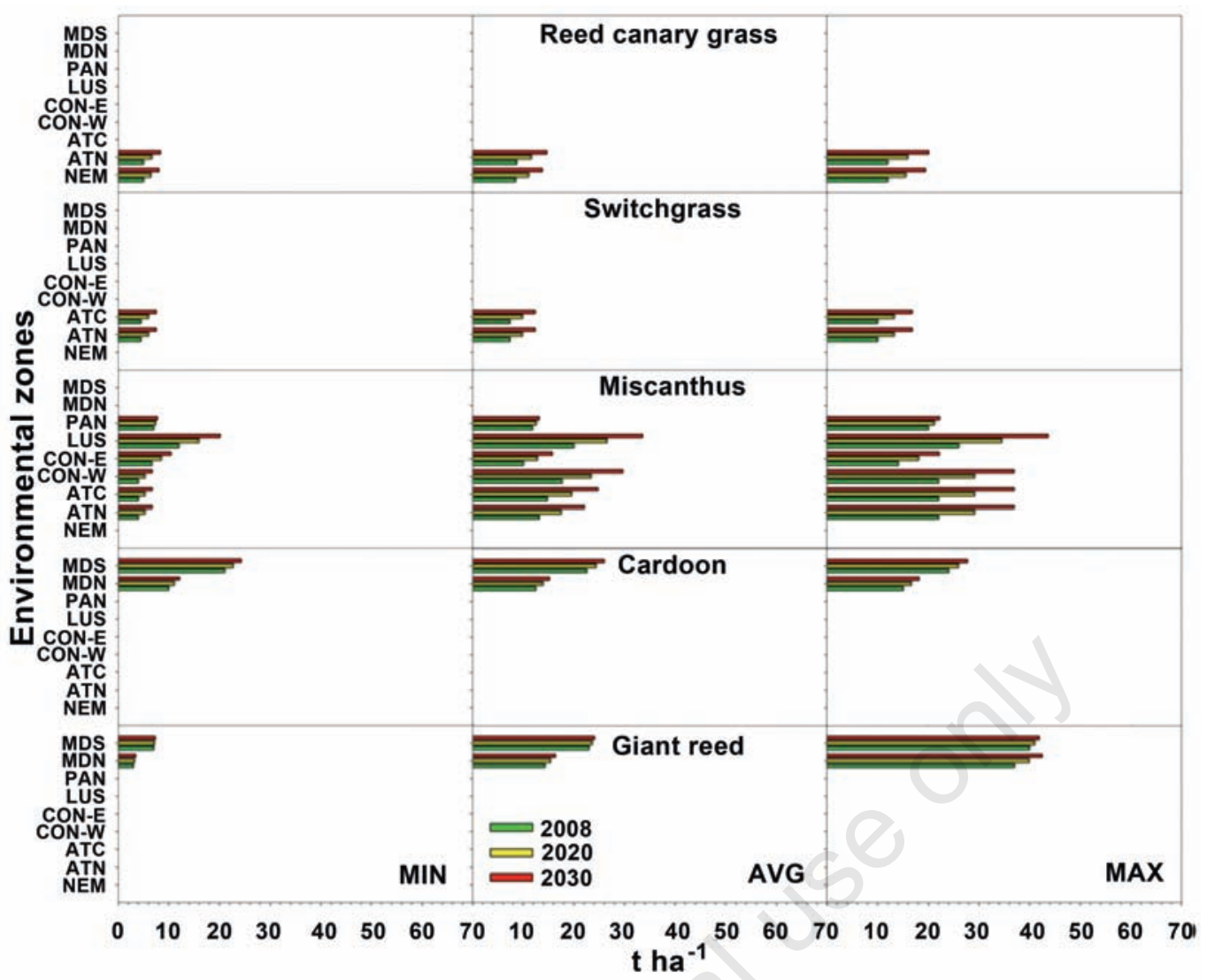

Figure 3. Base case and forecasts of minimum, average and maximum crop yields of herbaceous, perennial, lignocellulosic crops at 2020 and 2030 scenario (NEM, Nemoral; CON-W, Continental west; CON-E, Continental east; ATN, Atlantic north, ATC, Atlantic central; LUS, Lusitanian; PAN, Pannonia; MDN, Mediterranean north; MDS, Mediterranean south).

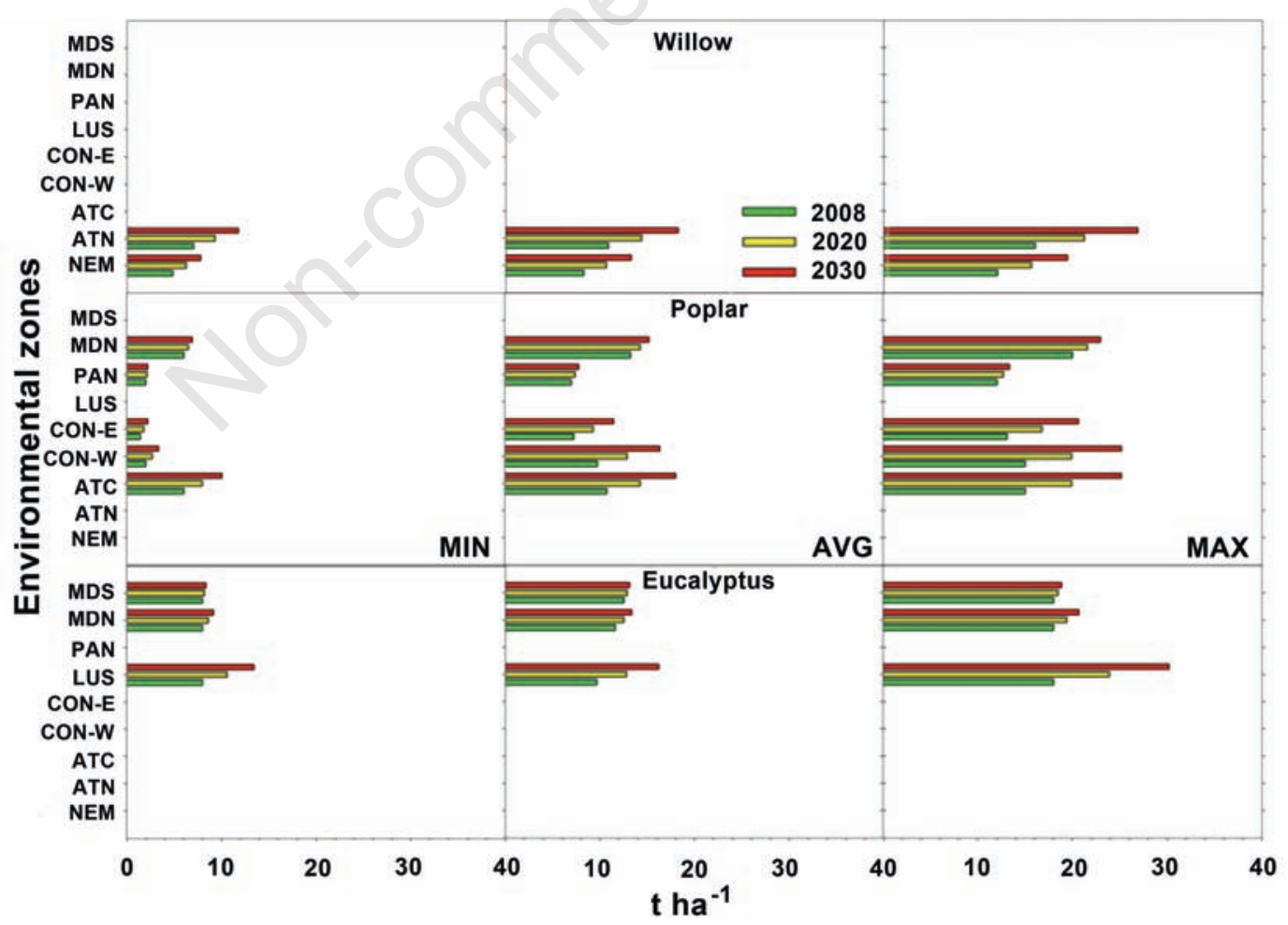

Figure 4. Base case and forecasts of minimum, average and maximum crop yields of short rotation coppice (SRC) at 2020 and 2030 scenario (NEM, Nemoral; CON-W, Continental west; CON-E, Continental east; ATN, Atlantic north, ATC, Atlantic central; LUS, Lusitanian; PAN, Pannonia; MDN, Mediterranean north; MDS, Mediterranean south). 
imum assumption and until $26 \mathrm{t} \mathrm{ha}^{-1}$ in LUS in the maximum assumption. In 2030 miscanthus yield will grow in all environment of cultivation; the best environment will be LUS (ranging from a minimum of 20 to a maximum of $43 \mathrm{tha}^{-1}$ ), mainly due to increase in rainfall, while the worst, PAN (from a minimum of 7.8 to a maximum of $22.2 \mathrm{t} \mathrm{ha}^{-1}$ ), due to the extreme temperatures during winter and summer period. Giant reed is well adapted to warm-temperate or subtropical growing conditions. Its yield ranges from 3 to $37 \mathrm{t} \mathrm{ha}^{-1}$ (minimum and maximum value, respectively) in MDN at current case and from 7 to $40 \mathrm{t}$ ha $^{-1}$ in MDS (Figure 3). In 2030 almost close production will be observed in both environments for the maximum assumption $(42 \mathrm{t}$ $\mathrm{ha}^{-1}$ ), while in the average 18 and $24 \mathrm{tha}^{-1}$, respectively in MDN and MDS. Cardoon, as well as giant reed, is very suitable to the drought conditions of the central and southern Mediterranean area where its growing season lasts from autumn/winter to late summer. Yield increases will be expected both in MDN (from 12 to $15 \mathrm{t} \mathrm{ha}^{-1}$ in the average) and MDS (from 22 to $26 \mathrm{t} \mathrm{ha}^{-1}$ in the average), in 2030 scenario (Figure 3). As for reed canary grass, willow has a relatively high resistance to frost, so among short rotation coppice it is well adapted to colder climate as NEM and ATN. In the average assumption yields will grown from the actual 8.2 to $13 \mathrm{tha}^{-1}$ in NEM (2030) and from 10.8 to $18 \mathrm{t} \mathrm{ha}^{-1}$ in ATN (2030) (Figure 4). In the maximum assumption willow could reach $26 \mathrm{t} \mathrm{ha}^{-1}$ in ATN in 2030. Poplar can be grown in warmer areas than willow, with highest yield in MDN followed by ATC (13 and $10.7 \mathrm{t} \mathrm{ha}^{-1}$ in the current case and in the average); however in 2030 ATC will be the most productive environment $\left(18 \mathrm{tha}^{-1}\right.$ in the average assumption) followed by CON-W and MDN (16.3 and $15.2 \mathrm{t}$ $\mathrm{ha}^{-1}$ ), while PAN and CON-E the most unproductive ones (Figure 4). Highest yields of eucalyptus in 2030 scenario are foreseen in LUS (min 13.4, average 16.2, max $30.2 \mathrm{t} \mathrm{ha}^{-1}$ ), while in MDN and MDS are lower and very close between them (18.9 and 20.6 in the maximum assumption, respectively) (Figure 4).

The increase in biomass yield of these two energy crop categories is supported by the fact that in the near future, breeding programs and crop management will be the major drivers for the development and introduction of these species in the ordinary cropping systems. Moreover, an increase in crop growing cycle is expected due to the increase in temperatures in those environments where water is not a limiting factor.

\section{Total biomass achievable in Europe}

The total area potentially available for non-food crops in the studied environmental zones (NEM, ATN, ATC, CON-W, CON-E, LUS, PAN, MDN and MDS) was estimated to be 12.36 million ha (Mha) in the current situation (2003-2007), 19.5 Mha in 2020 and 24.9 Mha in 2030. Table 2 gives an overview of the surplus land in the selected environmental zones. As it can be seen, the surplus land will tend to increase in all environmental zones. The minor increases of surplus land will be in the Mediterranean regions because of the expected reductions in food crops yield in these areas. By splitting the surplus land between climate zones falling in the EU-15 and EU-12 countries, it can be observed that in the base case most of the surplus land falls in the EU15 area, being equal to $74.5 \%$ (9.2 Mha) of the total (Table 8). This dif-

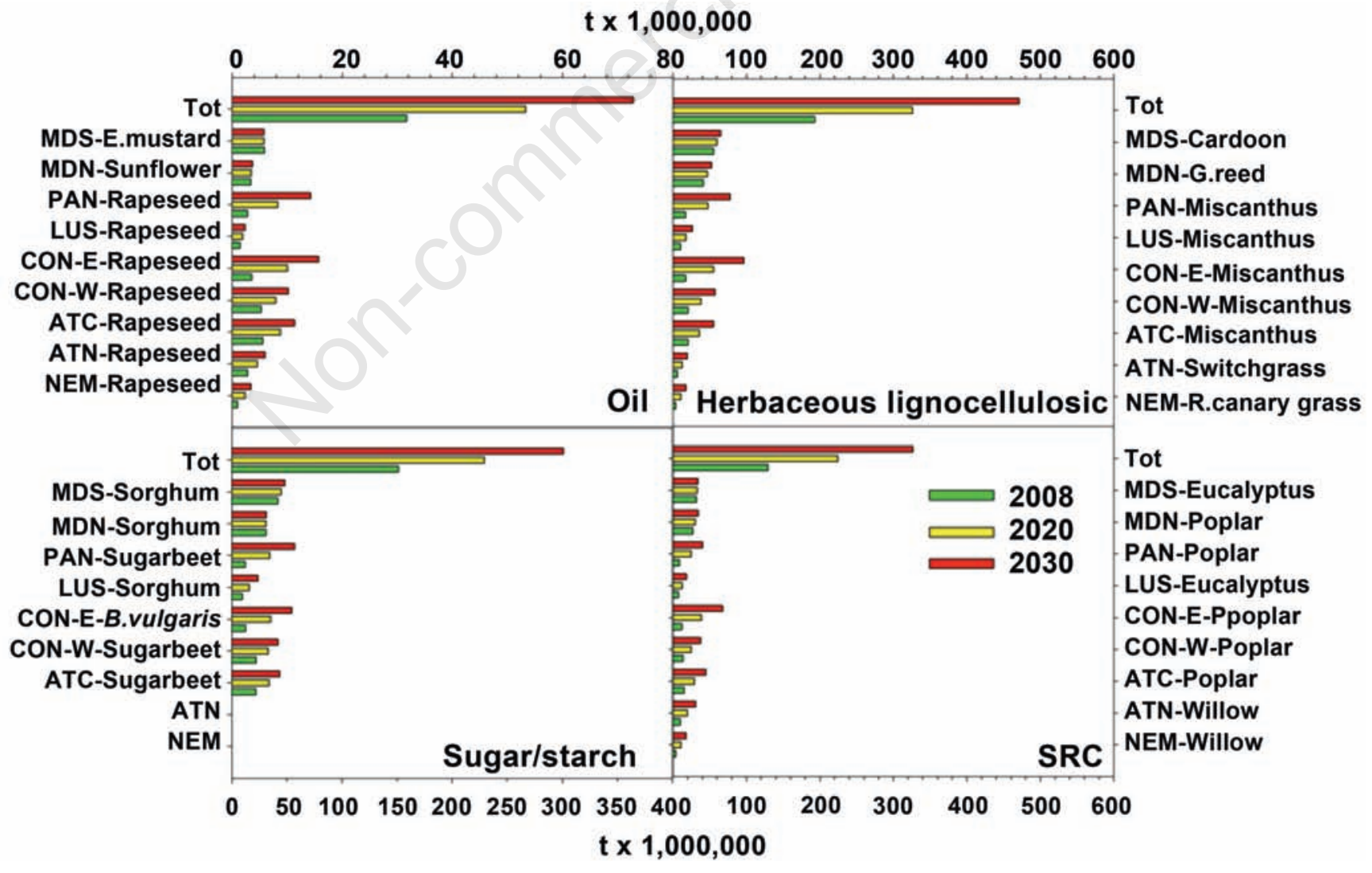

Figure 5. Forecasts of the total average biomass achievable in the European surplus land at 2020 and 2030 scenarios (NEM, Nemoral; CON-W, Continental west; CON-E, Continental east; ATN, Atlantic north, ATC, Atlantic central; LUS, Lusitanian; PAN, Pannonia; MDN, Mediterranean north; MDS, Mediterranean south). 
ference will tend to decrease and will be equal to $11.5 \mathrm{Mha}$ in the EU15 and 8.0 Mha in the EU-12 (2020 forecast); the abovementioned difference will tend to further decrease in 2030 with 13.1 Mha (52.7\%) vs 11.8 Mha (47.3\%), respectively for the EU-15 and EU-12. This greater increase of surplus land in the future projections observed in the EU12 countries can be ascribed to the expected yield increases of food crops in these areas mainly due to the introduction of new varieties, higher crop mechanization and improvement of agricultural practices.

Using the average values of projections of future yields (2020 and 2030) and the surplus lands obtained in different climatic zones, it is possible to hypothesize the future production of biomass in all European surplus lands. If we assume to cultivate all the surplus land with oil crops, and choosing the best crop for each environmental zone, it is possible to increase the production from 31.7 million tons (Mt) obtained in the base case to $72.9 \mathrm{Mt}$ in 2030 (Figure 5). Analyzing only sugar/starch crops we could obtain from 151.2 Mt in the base case to $301 \mathrm{Mt}$ in 2030. Assuming to cultivate only herbaceous lignocellulosic crops we can get from a production of $192.8 \mathrm{Mt}$ to $471.1 \mathrm{Mt}$, while from 129.4 to $326.8 \mathrm{Mt}$ if only SRC are cultivated.

\section{Discussion}

The general climatic constrains on agriculture production are mainly the length of growing season, precipitations, temperature, early and late frost risk of the different European environmental zones. In northern countries (NEM and ATN) the length of growing season, solar radiation, late spring and early autumn frost are typically climatic constrains which limit the productivity of crops. Abundant precipitations and satisfactory length of the growing season favour agricultural production and yields in central-western part of Europe (ATC and LUS). In southern regions (MDN and MDS), water availability increases risk of drought stress and crop evapotranspiration, however, the longer growing season, favourable temperatures and free frost risk enable a large choice of energy crops. The use of irrigation or drought resistant species and varieties for these environmental conditions are predominant strategies for spring sown crops. In the CON and most eastern part of Europe (PAN), with their amplitude of annual temperature cycle, dry summer conditions and high frost risk in autumn or late spring causes a limiting factor in the energy crop choice and crop yield. The most productive regions in these environments are located in CON-W and lowland regions of Hungarian plains (Maracchi et al., 2005). Our analysis of the only climatic change on agricultural productivity leads to a general yield reduction in most southern and eastern environmental zones and a general increase in the central-northern ones. At middle and higher latitudes, global warming will lead to less severe winters, extending the length of growing season and allowing early planting in the spring and early maturation and harvesting of annual and perennial crops. Vice versa, the general annual temperature raise will decrease the length of growing season resulting in accelerating development, higher evatranspiration and hastened maturation (Olesen and Bindi, 2002), while reduction in annual precipitation will cause severe water deficits which may lead to lower yields in southern.

The expected increase in atmospheric $\mathrm{CO}_{2}$ concentration will, in part, mitigate these negative effects. It has been proved that $\mathrm{C} 3$ crops positively respond to increased atmospheric $\mathrm{CO}_{2}$ concentration, increasing net photosynthesis (Ainsworth and Ort, 2010), reducing transpiration and stomatal conductance due to reduced stomatal aperture and density (Drake et al., 1997), reducing the dark transpiration due to a reduction in activity of respiratory enzymes (Ogren, 1984; Bunce, 1994) and increasing water use efficiency, both in C3 and C4 species (Olesen and Bindi, 2002). On the other hand, rise in atmospheric $\mathrm{CO}_{2}$ concentration will lead to higher greenhouse effects and
Table 8. Surplus land in EU-15 and EU-12 and allocation of the total estimated production according to crop category end use (oil, sugar/starch, herbaceous lignocellulosic and short rotation coppice).

\begin{tabular}{|c|c|c|c|c|c|}
\hline \multirow[b]{2}{*}{ Available land } & \multicolumn{3}{|c|}{$\begin{array}{c}\text { West (EU-15) } \\
200820202030\end{array}$} & \multicolumn{2}{|c|}{$\begin{array}{r}\text { East (EU-12) } \\
200820202030\end{array}$} \\
\hline & & & & & \\
\hline Surplus land (Mha) & 9.21 & 11.47 & 13.13 & 3.15 & $8.03 \quad 11.80$ \\
\hline Surplus land (\%) & 74.5 & 58.8 & 52.7 & 25.5 & $41.2 \quad 47.3$ \\
\hline Biomass yield partitioning & & & & & \\
\hline Oil (\%) & 78.5 & 63.3 & 56.6 & 21.5 & 36.7 \\
\hline Sugar/starch (\%) & 86.9 & 74.5 & 68.6 & 13.1 & 25.5 \\
\hline Herbaceous lignocellulosic (\%) & 82.0 & 68.6 & 63.6 & 18.0 & 31.4 \\
\hline Short rotation coppice (\%) & 83.0 & 70.1 & 65.2 & 17.0 & 29.9 \\
\hline
\end{tabular}

water shortage, especially in southern Europe, which in turn will negatively affect the crop productivity. Whether and to what extent the rise in $\mathrm{CO}_{2}$ will offset the more severe drought conditions is still a controversial matter. Recent studies reported that the average crop yield across Europe will change from $-3 \%$ to $1 \%$ due to climate change, from $11 \%$ to $32 \%$ due to the increase in atmospheric $\mathrm{CO}_{2}$ concentration, from $25 \%$ to $136 \%$ due to the advances in technology (Ewert et al., 2005; Rounsevell et al., 2005, 2006). Accordingly, in our study the technological development has been the factor with the higher impact on future crop yield in the different environmental zones. Efficient informatics inclusion and seasonal forecast on agriculture, crop breeding to overcome specific environmental constrains and crop management, including cultivation timing, tillage practices, fertilization practices, new genotypes and varieties introduction, crop protection and assurance will play a key role in strategies of adaption and mitigations to climate change (Olesen et al., 2011). The European Commission has planned to strongly increase the investment on bioenergy crops in short term as important renewable alternatives to replace fossil fuels. Therefore, energy crops in general and perennial no-food ones in particular will enjoy substantial financial support in terms of research, development, crop adaptability and tolerance, as in the case of the Seventh European Framework Programs. Overall, our results, based on literature reviews, relevant research papers and expert judgments, show that the possibilities to successfully grow crops for oilseeds, sugar/starch and solid biofuels are expected to strongly increase in northern Europe, mostly due to higher summer temperatures, and moderately increase in southern Europe due to water shortage mitigated by technological development. This trend is initially slightly visible (2020) and then it becomes much more pronounced (2030 scenarios). At the same time, while we are reporting the optimal allocation among a crop category (oil, sugar/starch and soild biofuel) in the selected environment, a wider window in the choice of bioenergy crop could be possible. Therefore, even though the choice of bioenergy crops in our analysis is restricted to a very small number of crops, with alternative agronomy strategies (e.g. earlier sowing) or selection programs, new genotypes with higher drought, frost or other climatic constrains adaptability could be introduced in southern and northern environments, respectively. The estimated total biomass production in Europe, on the basis of future yields and surplus land made available for energy crops, may not be sufficient to meet the needs of bioenergy supply as claimed in the European directive 2009/28/EC (European Commission, 2009), which imposes an obligation to increase the amount of the renewable energy in the EU to $20 \%$ of the total energy consumption by 2020 , with $10 \%$ biofuels in the transport sector in order to reduce the $\mathrm{CO}_{2}$ emissions by $20 \%$ compared to 2005 . The EU has estimated that 30.8 million tons of oil equivalent (Mtoe) will be needed to satisfy the obligation of $10 \%$ of biofuel sharing in 2020; this would stand at 48 million tons (Mt) of bioethanol or 35 
Mt of biodiesel (considering that 1 toe correspond to $1.56 \mathrm{t}$ of bioethanol or $1.14 \mathrm{t}$ of biodiesel) (Eurobserver, 2009). However, the gap of bioethanol or biodiesel production could be reduced through the introduction of high yielding genotypes selected for improved oil or sugar/starch content and/or through the development of high efficient technologies for second generation biofuel (Scordia et al., 2010), as claimed by the European Commission.

\section{Conclusions}

Future yields of energy crops will increase, especially in areas of central and northern Europe, due to climate change. The increase in $\mathrm{CO}_{2}$ concentration will lead to greater efficiency of use of resources, while the temperature increase will provide more favourable conditions for the production and introduction of new species. On the other hand, in areas of southern and eastern Europe, climate change will have a negative effect on crops, mainly due to possible water deficits and the possible extreme weather events (e.g. prolonged heat waves, hail, storms) that will increase the variability of annual production and lead to a contraction of surfaces suitable for the cultivation of traditional species.

Technological development could however mitigate these negative effects through the introduction of new varieties and improved crop management. The estimated total biomass production in Europe, on the basis of future yields and surplus land made available for energy crops, may not be sufficient to meet the needs of bioenergy supply as claimed in the European directive 2009/28/EC. The introduction of high yielding genotypes selected for improved oil or sugar/starch content and/or through the development of high efficient technologies for second generation biofuel production could reduce this gap.

\section{References}

Ainsworth EA, Ort DR, 2010. How do we improve crop production in a warming world? Plant Physiol. 154:526-530.

Alexandrov VA, Hoogenboom G, 2000. The impact of climate variability and change on crop yield in Bulgaria. Agric. Forest Meteorol. 104: 315-327.

Alexopoulou E, 2010. Future Crops for Food, Feed, Fiber and Fuel - 4F CROPS. Seventh Framework Programme of the European Commission, Grant Agreement nr. 212811 (www.4fcrops.eu).

Audsley E, Pearn KR, Simota C, Cojocaru G, Koutsidou E, Rounsevell MDA, Trnka M, Alexandrov V, 2006. What can scenario modelling tell us about future European scale agricultural land use, and what not? Environ. Sci. Policy 9:148-162.

Bunce JA, 1994. Responses of respiration to increasing atmospheric carbon dioxide concentrations. Physiol. Plantarum 90:427-430.

Cardone M, Mazzoncini M, Menini S, Rocco V, Senatore A, Seggiani M, Vitolo S, 2003. Brassica carinata as an alternative oil crop for the production of biodiesel in Italy: agronomic evaluation, fuel production by transesterification and characterization. Biomass Bioenerg. 25:623-636.

Ceulemans R, Mcdonald AJS, Pereira JS, 1996. A comparison among eucalypt, poplar and willow characteristics with particular reference to a coppice, growth-modelling approach. Biomass Bioenerg. $11: 215-231$

Copani V, Cosentino SL, Sortino 0, Terranova G, Mantineo M, Virgillito S, 2009. Agronomic and energetic performance of Brassica carinata A. Braun in Southern Italy. Proc. 17th Eur. Biomass Conf. and Exhibition "From Research to Industry and Markets". Hamburg, Germany, 3:166-170.
Cosentino SL, Copani V, D'agosta G, Sanzone E, Mantineo M, 2006. First results on evaluation of Arundo donax L. clones collected in Southern Italy. Ind. Crop Prod. 23:212-222.

Cosentino SL, Foti S, Venturi G, Giovanardi R, Copani V, Mantineo M, D'Agosta G, Bezzi G, Tassan Mazzocco G, 2005. Colture erbacee annuali e poliennali da biomassa per energia di possibile coltivazione in Italia. Agroindustria 4:35-48.

Cosentino SL, Mantineo M, Testa G, 2012. Water and nitrogen balance of Sweet sorghum (Sorghum bicolor Moench (L.)) cv. keller under semi-arid conditions. Ind. Crop. Prod. 36:329-342.

Drake BG, Gonzalez-Meler MA, Long SP, 1997. More efficient plants: a consequence of rising atmospheric C02? Ann. Rev. Plant Physiol. Plant Mol. Biol. 48:609-639.

Elbersen HW, Christian DG, El Bassem N, Bacher W, Sauerbeck G, Alexopoulou E, Sharma N, Piscioneri I, de Visser P, van den Berg D, 2001. Switchgrass variety choice in Europe. Final Report FAIR 5CT97-3701 "Switchgrass". Available from: http://www.switchgrass. nl/pdf/Sw-FinalRep-chapter5.pdf

Ericsson K, Nilsson LJ, 2006. Assessment of the potential biomass supply in Europe using a resource-focused approach. Biomass Bioenerg. 30:1-15.

EurObserv'ER le journal des énergies renouvelables, 2009. Biofuels barometer, N. 192 - 2009. Available from: http://www.eurobserver.org/pdf/baro192.pdf

European Biodiversity Observation Network, 2010. Available from: http://www.ebone.wur.nl/UK/Project information and products/ European Environmental Stratification

European Commission, 2009. Commission Decision of 23 April 2009 on the promotion of the use of energy from renewable sources and amending and subsequently repealing Directives 2001/77/EC and 2003/30/EC, 2009/28/EC. In: Official Journal, L140, 05/06/2009, pp 16-62.

European Commission, Directorate-General for Agriculture and Rural Development, 2007. Prospects for agricultural markets and income in the European Union 2007-2014. Accessed on: 12 April 2012. Available from: http:// ec.europa.eu/agriculture/publi/caprep/ prospects2007a/index_en.htm

European Environmental Agency, 2007. Estimating the environmentally compatible bioenergy potenti al from agriculture, EEA Technical Report No. 12/2007, Copenhagen, Denmark.

Ewert F, Rounsevell MDA, Reginster I, Metzger MJ, Leemans R, 2005. Future scenarios of European agricultural land use. I. Estimating changes in crop productivity. Agric. Ecosyst. Environ. 107:101-116.

Fischer G, Hizsnyik E, Prieler S, van Velthuizen H, 2007. Assessment of biomass potentials for biofuel feedstock production in Europe: methodology and results. Available from: http://www.refuel.eu/ fileadmin/refuel/user/docs/Refuel-D6-Jul2007-final6.pdf

Giannakopoulos C, Le Sager P, Bindi M, Moriondo M, Kostopoulou E, Goodess CM, 2009. Climatic changes and associated impacts in the Mediterranean resulting from a $2^{\circ} \mathrm{C}$ global warming. Global Planet. Change 68:209-224.

Harrison PA, Butterfield RE, 1996. Effects of climate change on Europewide winter wheat and sunflower productivity. Clim. Res. 7:225241.

Heaton EA, Clifton-Brown J, Voigt TB, Jones MB, Long SP, 2004. Miscanthus for renewable energy generation: European Union experience and projections for Illinois. Mitig. Adapt. Strateg. Glob. Change 9:433-451.

Iglesias A, Rosenzweig C, Pereira D, 2000. Agricultural impacts of climate change in Spain: developing tools for a spatial analysis. Global Environ. Change 10:69-80.

Intergovernmental Panel on Climate Change, 2000. Special report emission scenarios. Available from: http://www.ipcc.ch/pdf/specialreports/spm/sres-en.pdf 
mate models. Climatic Change 81:123-143.

Jongman RHG, Bunce RGH, Metzger MJ, Mucher CA, Howard DC, Mateus VL, 2006. Objectives and application of a statistical environmental stratification of Europe. Landscape Ecol. 21:409-419.

Kauter D, Lewandowski I, Claupein W, 2003. Quantity and quality of harvestable biomass from Populus short rotation coppice for solid fuel use - a review of the physiological basis and management influences. Biomass Bioenerg. 24:411-427.

Keoleian GA, Volk TA, 2005. Renewable energy from willow biomass crops: life cycle energy, environmental and economic performance. Crc Cr. Rev. Plant. Sci. 24:385-406.

Krasuska E, Cadórniga C, Tenorio JL, Testa G, Scordia D, 2010. Potential land availability for energy crops production in Europe. Biofuel. Bioprod. Bior. 4:658-673.

Kunikowski G, Rutkowska-Filipczak M, Wróbel A, Gańko E, 2006. Energy crops potentials inventory results. Project report of the 6th Framework Programme project Renewable Fuels for Advanced Powertrains (RENEW), No. D.:5.01.07. Available from: http://www.renew-fuel.com/

Lewandowski I, Scurlock JMO, Lindvall E, Christou M, 2003. The development and current status of perennial rhizomatous grasses as energy crops in the US and Europe. Biomass Bioenerg. 25:335-361.

Mantineo M, D'Agosta GM, Copani V, Patanè C, Cosentino SL, 2009. Biomass yield and energy balance of three perennial crops for energy use in the semi-arid Mediterranean environment. Field Crop. Res. 114:204-213.

Maracchi G, Sirotenko 0, Bindi M, 2005. Impacts of present and future climate variability on agriculture and forestry in the temperate regions: Europe. Climatic Change 70:117-135.

Metzger MJ, Bunce RGH, Jongman RHG, Mücher CA, Watkins JW, 2005. A climatic stratification of the environment of Europe. Global Ecol. Biogeogr. 14:549-563.

Ogren WL, 1984. Photorespiration: pathways, regulation, and modification. Ann. Rev. Plant Physio. 35:415-442.

Olesen JE, Bindi M, 2002. Consequences of climate change for European agricultural productivity, land use and policy. Eur. J. Agron. 16:239-262.

Olesen JE, Carter TR, Diaz-Ambrona CH, Fronzek S, Heidmann T, Hickler T, Holt T, Minguez MI, Morales P, Palutikov J, Quemada M, Ruiz-Ramos M, Rubak G, Sau F, Smith B, Sykes M, 2007. Uncertainties in projected impacts of climate change on European agriculture and ecosystems based on scenarios from regional cli-
Olesen JE, Trnka M, Kersebaum KC, Skjelvag A0, Seguin B, PeltonenSainio P, Rossi F, Kozyra J, Micale F, 2011. Impacts and adaptation of European crop production systems to climate change. Eur. J. Agron. 34:96-112.

Rettenmaier N, Köppen S, Gärtner S0, Reinhardt GA, 2010. Life cycle assessment of selected future energy crops for Europe. Biofuel. Bioprod. Bior. 4:620-636.

Rötter RP, Carter TR, Olesen JE, Porter JR, 2011. Crop-climate models need an overhaul. Nature Climate Change 1:175-177.

Rounsevell MDA, Ewert F, Reginster I, Leemans R, Carter TR, 2005. Future scenarios of European agricultural land use. II. Projecting changes in cropland and grassland. Agric. Ecosyst. Environ. 107:117-135.

Rounsevell MDA, Reginster I, Araújo MB, Carter TR, Dendoncker N, Ewert F, House JI, Kankaanpää S, Leemans R, Metzger MJ, Schmit C, Smith P, Tuck G, 2006. A coherent set of future land use change scenarios for Europe. Agric. Ecosyst. Environ. 114:57-68.

Scordia D, Cosentino SL, Jeffries TW, 2010. Second generation bioethanol production from Saccharum spontaneum L. ssp. aegyptiacum (Willd.) Hack. Bioresource Technol. 101:5358-5365.

Tilman D, Socolow R, Foley JA, Hill J, Larson E, Lynd L, Pacala S, Reilly J, Searchinger T, Somerville C, Williams R, 2009. Beneficial biofuels-the food, energy, and environment trilemma. Science 325:270271.

Tubiello FN, Donatelli M, Rosenzweig C, Stockle C0, 2000. Effects of climate change and elevated CO2 on cropping systems: model predictions at two Italian locations. Eur. J. Agron. 13:179-189.

Tuck G, Glendining MJ, Smith P, House JI, Wattenbach M, 2006. The potential distribution of bioenergy crops in Europe under present and future climate. Biomass Bioenerg. 30:183-197.

Van Dam J, Faaij APC, Lewandowski I, Fischer G, 2007. Biomass production potentials in Central and Eastern Europe under differ ent scenarios. Biomass Bioenerg. 31:345-366.

Venendaal R, Jørgensen U, Fosters CA, 1997. European energy crops: a synthesis. Biomass Bioenerg. 13:147-185.

Venturi P, Venturi G, 2003. Analysis of energy comparison for crops in European agricultural systems. Biomass Bioenerg. 25:235-255.

Zegada-Lizarazu W, Elbersen W, Cosentino SL, Zatta A, Alexopoulou E, Monti A, 2010. Agronomic aspects of future energy crops in Europe. Biofuel. Bioprod. Bior. 4:674-691. 